Article

\title{
Detection of Land Use/Land Cover Changes and Urban Sprawl in Al-Khobar, Saudi Arabia: An Analysis of Multi-Temporal Remote Sensing Data
}

\author{
Muhammad Tauhidur Rahman \\ Department of City and Regional Planning, King Fahd University of Petroleum and Minerals, KFUPM Box 5053, \\ Dhahran 31261, Saudi Arabia; mtr@kfupm.edu.sa; Tel.: +966-13-860-7364; Fax: +966-13-860-3857 \\ Academic Editor: Wolfgang Kainz \\ Received: 7 September 2015; Accepted: 1 February 2016; Published: 6 February 2016
}

\begin{abstract}
While several studies examined land use and land cover changes in the central and western parts of Saudi Arabia, this study is the first to use remote sensing data to examine the decadal land cover changes in Saudi Arabia's eastern coastal city of Al-Khobar between 1990 and 2013. Specifically, it utilized ISODATA classification method to classify Landsat TM, ETM+, and OLI data collected from 1990, 2001, and 2013 and then detected changes in the land cover within the study area. It then measured urban sprawl by calculating the relative Shannon's entropy index values for the three years. With overall classification accuracies greater than $85 \%$, the results show that urban built-up areas increased by $117 \%$ between 1990 and 2001 and $43.51 \%$ from 2001 to 2013. Vegetation increased by $110 \%$ from 1990 to 2001 and by 52\% between 2001 and 2013. The entropy index values of 0.700 (1990), 0.779 (2001), and 0.840 (2013) indicates a high rate of urban sprawl and the city dispersing near the outskirts and towards the neighboring cities of Dhahran and Dammam. Future studies should examine the current challenges faced by the city's residents due to urban expansion and attempt to find ways to resolve them in the near future.
\end{abstract}

Keywords: change detection; multi-temporal remote sensing data; spatiotemporal analysis; urban sprawl; entropy; Al-Khobar; Saudi Arabia

\section{Introduction}

Urban encroachment and land use/land cover (hereafter LULC) changes around fast-growing cities in the developing world has drawn considerable attention from urban geographers and city and regional planners. Population growth in terms of increased population density is seen as the key factor directly inducing LULC changes and urban sprawl [1-3]. Population growth demands construction of new residential, commercial, utility, and transport infrastructures. They also require conversion of forests, farmlands, and bare soils, causing LULC changes and urban sprawl. Urban sprawl has its threshold limits. At the lowest end of the spectrum, a city remains uniform and vulnerable to change while rapid unplanned urban sprawl exceeding its maximum threshold limit creates chaos and deteriorates the quality of city transportation and utility services. Hence an organized and planned urban sprawl is essential to build a socially, economically, and environmentally sustainable society $[4,5]$.

Population growth and urban sprawl indicate regional economic growth. However, human-induced deforestation and modification of natural landscape to construct buildings, water supplies, sewage, and transport networks exert various negative impacts on land and soil, biodiversity, vegetation, noise level, air and water qualities, and leads to an overall environmental degradation both inside a city and in its immediate vicinity [6-10]. In addition, major construction works transform cities into impervious surfaces in which formation of heat islands contributes to local and regional climate changes and increases the occurrences of floods and other natural hazards [11-16]. Urban sprawl also 
increases land values, costs of living, economic disparities, and social stratification [17,18]. In order to reduce these negative impacts of urban sprawl and for planning a city's future expansion, both local and regional urban planners, government officials, and policy makers need careful examination of its current LULC patterns and their spatio-temporal changes. They also need to assess the degree of urban sprawl that is occurring within the city with respect to population growth and economic development $[19,20]$.

The study of LULC changes requires an analysis of a large amount of spatio-temporal data that were traditionally collected through ground-based field surveys. Over the past couple of decades, rapid improvements in remote sensing technologies, especially due to their affordable prices, large spatial coverages, repetitive observations, and efficient data-processing capabilities, has encouraged urban researchers and city planners to use remote sensing data to examine the spatio-temporal LULC changes and urban sprawl [21-29]. The methods of identification of LULC changes using remote sensing data fall into pre-classification and post-classification categories [30]. The pre-classification method processes a set of multi-temporal remote sensing images to create maps identifying areas of change or no-change in LULC without classifying the nature of changes [11,30-33]. In contrast, the post-classification method compares two classified temporal remotely sensed images to produce maps that would depict changes within and between LULC classes over time. Therefore, it helps researchers and planners to detect the nature and direction of LULC changes and urban sprawl around cities [30,34,35].

In the Kingdom of Saudi Arabia, Jeddah and Riyadh were the two major traditional cities besides the Islamic holy cities of Mecca and Medina. However, after the exploration of petroleum in the Eastern province of the kingdom in the late 1930s, the city of Dammam and its surrounding old fishing villages quickly grew into large cities during the 1940s and 1950s. The city of Al-Khobar (also known as Khobar or Al-Khubar), which was one of those old fishing villages adjacent to Dammam, was established in 1940. Currently, Dammam-Daharan-Khobar forms a major "triplet" city metropolis in the Eastern province that has experienced rapid population growth since 1990. Of the three cities, Dammam is the regional capital of the Eastern province, while Daharan houses the Saudi Arabian Oil Company (Saudi Aramco) and the King Fahd University of Petroleum and Minerals (KFUPM) with a regional airport and a Saudi Air Force Base. Both cities were already compact in the 1990s. Thus, any population growth and urban development in the area over the past two decades occurred in Al-Khobar. The total population of Khobar increased from 141,981 in 1990 to 456,559 in 2001 and to 679,988 in 2013 [3,36]. As the population grew, rapid construction of residential, economic, and transportation infrastructures required human modification of natural landscapes.

Numerous studies have examined the LULC changes in Saudi cities using remote sensing data. Al-Harbi examined the expansion of agricultural lands in Tabuk city in 2003 by calculating the Ratio Vegetation Index (RVI) using Landsat TM data [37]. He conducted a follow-up study in 2010 by combining Landsat TM 5 and Spot 5 data to analyze agricultural change in the area [38]. Alwashe and Bokhari [39] used Landsat TM data to study vegetation changes in the city of Al-Madinah. Al-Gaadi, Samdani, and Patil used Landsat TM and ETM+ datasets and Normalized Difference Vegetation Index (NDVI) to detect land cover changes in the Dirab region in the western parts of Riyadh [40]. In another study, authors in [41] analyzed Landsat MSS, Landsat TM, and ASTER data to examine the urban expansion of Riyadh. For the city of Jeddah, authors in [42] used a combination of aerial photos, SPOT satellite imageries, and Jeddah's master plan to examine the patterns of urban expansion over the past four decades and their relationships with the development of urban transportation systems. The existing studies have assessed urban growth and changes mostly in the cities of central and western parts of the kingdom. Only recently, authors in [3] analyzed GIS data and identified population growth as the key factor inducing urban sprawl in the northern part of Al-Khobar city during 1980-2005. However, this study has not examined the nature of LULC changes that occurred as a result of the population growth in the city. In addition, while the city's population has grown even faster during the last decade and several noticeable changes occurred in the LULC patterns, there is an urgent need to 
examine the temporal LULC changes in this city. In order to formulate an environmentally sustainable land use plan for future expansion of this fast-growing city, it is extremely important to examine the dynamics of LULC changes, population growth, and the rate of urban sprawl that occurred in the city over the past two decades.

This present study examines the LULC changes and the nature of urban sprawl in the city of Al-Khobar using remotely sensed data for the years 1990, 2001, and 2013. It aims to classify LULC types in each year; detect changes that occurred in each LULC class; and measure the rate and direction of urban sprawl in response to population growth in the city over the past two decades. Section 2 describes the study area, data, and methods used in the study while the results and the discussions of the findings are presented in Sections 3 and 4. Finally, concluding remarks and directions for future research will be offered in Section 5.

\section{Materials and Methods}

\subsection{Study Area}

With an area of $256 \mathrm{~km}^{2}$, the city of Al-Khobar $\left(26^{\circ} 1^{\prime} \mathrm{N}\right.$ and $\left.50^{\circ} 5^{\prime} \mathrm{E}\right)$ is the home of nearly 680,000 people. Almost $56 \%$ of them are Saudi nationals. The rest are expatriates from neighboring Arab, South and Southeast Asian, as well as European and North American countries [36]. The city experiences a desert climate characterized by hot and humid summers with temperatures reaching between $30-38{ }^{\circ} \mathrm{C}$ and mild cool and dry winters with temperatures ranging between $15-20^{\circ} \mathrm{C}$ [43]. The city is flat with an average elevation of $12 \mathrm{~m}$ above sea level and has a complex LULC pattern. The southern $184 \mathrm{~km}^{2}$ of the city is vacant sandy desert land. The northern $72 \mathrm{~km}^{2}$ is comprised of urban residential areas and commercial built-up areas; it also contains a long coastal water body overlapping a small band of planted vegetation, and two small manmade lakes inside the coastal highway in the southeast. Over the past few decades, urban expansion occurred within this northern part of the city and it was thus chosen as the area of interest for this study (Figure 1).

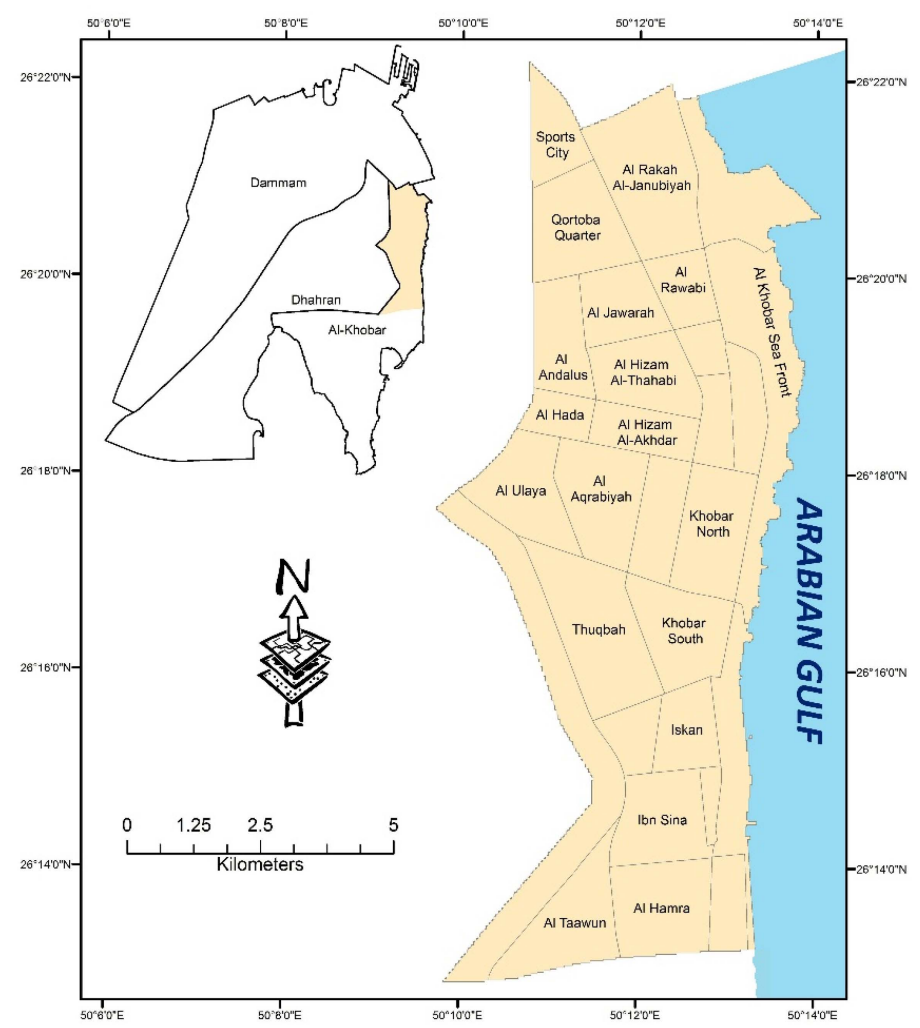

Figure 1. The study area with the major districts within the city of Al-Khobar. 


\subsection{Remotely Sensed Data Pre-Processing}

Three separate cloud-free Landsat ETM+ and TM data from 1990, 2001, and 2013 covering the study area were acquired freely from the U.S. Geological Survey's (USGS) Earthexplorer website (http://earthexplorer.usgs.gov/). The Landsat scenes were chosen for this study due to their affordability, availability, and medium to high spatial resolution. Details about the data are given in Table 1. Some researchers favor radiometric corrections of all remote sensing imageries [44]. However, for this study, USGS processed and provided level-one terrain-corrected (L1T) Landsat data in WGS84 geodetic datum, Universal Transverse Mercator map projection (UTM, Zone 39N), and north-up image orientation. Due to the L1T nature of the data, the radiometric and geometric distortions were already corrected before delivery $[45,46]$.

Table 1. Characteristics of the Landsat datasets used in the study.

\begin{tabular}{ccccccc}
\hline Acquisition Date & Sensor & Path/Row & $\begin{array}{c}\text { Spatial Resolution } \\
\text { of Reflective Bands }\end{array}$ & Cloud (\%) & $\begin{array}{c}\text { Number } \\
\text { of Bands }\end{array}$ & Format \\
\hline 16 August 1990 & Landsat 5 TM & $164 / 42$ & 30 & 0 & 7 & GeoTIFF \\
5 July 2001 & Landsat 7 ETM+ & $164 / 42$ & 30 & 0 & 7 & GeoTIFF \\
28 June 2013 & Landsat 8 OLI & $164 / 42$ & 30 & 5.17 & 11 & GeoTIFF \\
\hline
\end{tabular}

\subsection{Classification, Accuracy Assessment, and Change Detection}

The Anderson classification level I scheme was used to identify four LULC categories (water bodies, vegetation, built-up area, and bare soil) in the Landsat images (Table 2) [47]. A supervised maximum likelihood classification (MLC) method (using signatures from a total of 90 training sites chosen from the four LULC classes) was used to classify the Landsat images of the three years.

Table 2. Land cover classification scheme used in the study.

\begin{tabular}{|c|c|}
\hline Land Cover Type & Description \\
\hline Built-Up Area & $\begin{array}{l}\text { All types of manmade structures: residential, industrial, agricultural commercial } \\
\text { and services; transportation and utilities; mixed urban or built-up. }\end{array}$ \\
\hline Vegetation & $\begin{array}{c}\text { Trees, natural vegetation, gardens, parks and playgrounds, grassland, vegetated } \\
\text { lands, agricultural lands, and crop fields. }\end{array}$ \\
\hline Bare Soil & $\begin{array}{c}\text { Areas with no vegetation cover, sand, open space, bare soils, and uncultivated } \\
\text { agricultural lands. }\end{array}$ \\
\hline Water Bodies & Reservoirs, ponds, coastal water. \\
\hline
\end{tabular}

To assess the accuracy of the classification results, ground truth reference points were collected from 272 locations points (chosen through stratified sampling strategy) within the study area. A historical LULC paper map was created by the Al-Khobar municipality from a 1981 aerial photo (at a scale of 1:32,258). The map was later updated in 1991 and 2002 based on a ground field survey and data from the Khobar Planning Department. These paper maps were obtained from the Khobar municipality's office and were scanned, geometrically corrected with the Landsat imageries and the ground truth data, and digitized in ArcGIS. Furthermore, a high resolution GeoEye image (acquisition date of 18 June 2011) was also obtained from King Abdulaziz City for Science and Technology (KACST). The digitized 1991 and 2002 LULC maps, current GeoEye image, and the ground truth data were all used as reference sources to evaluate the accuracy of the classification results.

To present the accuracy assessment results, error matrices were created and examined in this study. Error matrices are the standard form of reporting site-specific classification errors [48]. They show the "contingency of the class to which each pixel truly belongs (columns) on the map unit to which it is allocated by the selected analysis (rows)" [49]. Furthermore, the producer's accuracy (PA), user's accuracy (UA), and the kappa coefficient were also calculated from the error matrix for each classified dataset. The overall accuracy of LULC classification using the maximum likelihood method 
was $74.85 \%, 80.6 \%$, and $82.0 \%$ with kappa coefficient of $0.62,0.69$, and 0.72 , respectively, for the years 1990, 2001, and 2013 (Table 3). The derived accuracy level was lower than the Anderson's standard $85 \%$ accepted overall accuracy level for LULC classification [47].

Considering the existence of complex, overlapping, and inaccessible LULC patterns in the study area, and lower accuracy level achieved in the MLC method, an unsupervised classification using the Iterative Self-Organizing Data Analysis Technique Algorithm (ISODATA) was used to achieve better accuracy in LULC classification. The resulting 15 classified classes were combined and reclassified into the previously mentioned four major urban land cover categories (Table 2). Finally, a 3 by 3 grid cell low-pass filtering was used to reduce the "salt-and-pepper" effect in the classified results.

When assessed for accuracy, the overall accuracy of LULC classification using the ISODATA algorithm was $85.6 \%, 88.5 \%$, and $93.4 \%$ with kappa coefficients of $0.80,0.84$, and 0.90 , respectively, for Landsat images for the years 1990, 2001, and 2013 (Table 4). As suggested by Ahmed et al. [23], the 2013 classification maps produced the highest overall accuracy and kappa coefficient values (for both MLC and ISODATA classification results) due to the availability of the field survey data and the high resolution GeoEye image. On the contrary, positional errors and errors during the digitization process of the LULC paper maps from 1991 and 2002 may have contributed to the low accuracy level for the classification results from 1990 and 2001 [50].

As discussed earlier, change detection of the earth's surface and landscape can be classified into two major categories: pre-classification and post-classification. The post-classification change detection method was used in this study by simply comparing two classified images. It has been used in numerous studies and resulted in a complete from-to change matrix showing the changes between each class [2,51-53]. Since the accuracies of the ISODATA classified results met the Anderson accuracy standard of $85 \%$ and were higher than the overall accuracy results produced by the MLC method, the unsupervised ISODATA classified results were used for the LULC change detection analysis.

Table 3. Summary of the error matrices for the 1990, 2001, and 2013 using the maximum likelihood classification method.

\begin{tabular}{|c|c|c|c|c|c|c|c|c|c|c|c|c|}
\hline & \multicolumn{3}{|c|}{ Producer's Accuracy } & \multicolumn{3}{|c|}{ User's Accuracy } & \multicolumn{3}{|c|}{ Overall Accuracy } & \multicolumn{3}{|c|}{ Kappa Coefficient } \\
\hline & 1990 & 2001 & 2013 & 1990 & 2001 & 2013 & 1990 & 2001 & 2013 & 1990 & 2001 & 2013 \\
\hline Water & 86.2 & 80 & 81.0 & 58.1 & 76.9 & 83.3 & & & & & & \\
\hline Vegetation & 60 & 85.7 & 87.5 & 69.2 & 75 & 79.5 & & & & & & \\
\hline Built-Up Area & 72.6 & 83.9 & 84.9 & 89.7 & 88.4 & 89.7 & 74.85 & 80.6 & 82.0 & 0.62 & 0.69 & 0.72 \\
\hline Bare Soil & 83.3 & 70.2 & 69.0 & 64.8 & 66.7 & 62.3 & & & & & & \\
\hline
\end{tabular}

Table 4. Summary of the error matrices for 1990, 2001, and 2013 using the ISODATA classification method.

\begin{tabular}{|c|c|c|c|c|c|c|c|c|c|c|c|c|}
\hline & \multicolumn{3}{|c|}{ Producer's Accuracy } & \multicolumn{3}{|c|}{ User's Accuracy } & \multicolumn{3}{|c|}{ Overall Accuracy } & \multicolumn{3}{|c|}{ Kappa Coefficient } \\
\hline & 1990 & 2001 & 2013 & 1990 & 2001 & 2013 & 1990 & 2001 & 2013 & 1990 & 2001 & 2013 \\
\hline Water & 100 & 100 & 98 & 100 & 100 & 100 & \multirow{4}{*}{85.6} & \multirow{4}{*}{88.5} & \multirow{4}{*}{93.4} & \multirow{4}{*}{0.80} & \multirow{4}{*}{0.84} & \multirow{4}{*}{0.90} \\
\hline Vegetation & 66.7 & 68.0 & 76 & 72.7 & 65.4 & 73.1 & & & & & & \\
\hline Built-Up Area & 74.3 & 84.3 & 93.1 & 92.6 & 92.5 & 92.2 & & & & & & \\
\hline Bare Soil & 97.3 & 95.9 & 97.9 & 75.3 & 82.5 & 100 & & & & & & \\
\hline
\end{tabular}

An overall accuracy for all detected changes that occurred between the three classified datasets was also assessed based on reference data by using the method proposed by Congalton and Green [54]. The reference data was created by visual interpretation and comparison of the Landsat images at the 272 previously mentioned sample reference points and were labeled as change or no change between the years 1990-2001, and 2001-2013 (for details see [55,56]). The classified maps were then examined for change/no change at the sample points and compared with the reference data. The overall accuracy for the change detection was $96 \%$ for $1990-2001$ and $98 \%$ for $2001-2013$. 


\subsection{Measurement of Urban Sprawl}

Measurement of urban sprawl can be based on population density and urban development density. Numerous studies have examined the relationship between growing population density and urban sprawl by computing the population density per unit of built-up surface area $[2,57,58]$. Urban sprawl was also measured by measuring the temporal change in ha of built-up area per person increase in population [59]. In this study, the impact of population growth on urban sprawl was examined by using the following equation to calculate the rate of change in built-up area per person increase in population during two census periods:

$$
U=\frac{\left(l_{i_{2}}-l_{i_{1}}\right)}{\left(p_{2}-p_{1}\right)}
$$

where, $U$ denotes the rate of urban sprawl in ha per person increase in population; $l_{i_{2}}$ and $l_{i_{1}}$ are respectively the area under $i$ th land use class in terminal year and base year; $p_{2}$ and $p_{1}$ are respectively population of the study area in terminal year and base year.

However, the most widely used method of measuring urban sprawl is by integrating Shannon's entropy and GIS tools. Shannon's entropy $\left(E_{n}\right)$ computes the density of urban development in order to measure its degree of concentration or dispersion among $n$ zones $[24,52,58-69]$. Other techniques such as the fractal dimension cannot identify the orientation and configuration of urban forms [70]. To perform the Shannon's entropy analysis, the three classified maps were first reclassified into two categories: built-up and non-built-up areas. Then $i$ th numbers of concentric circles or buffers are drawn from the center of the city. Since the birth of Islam, Arabian cities developed surrounding a grand mosque [71,72]. Khobar was no exception, and the grand mosque of Khobar was considered to be the original center of the city. Therefore, a total of 20 concentric buffer rings, each at $500 \mathrm{~m}$ apart, were drawn around it to cover the entire study area (Figure 2). The zonal statistics function of ArcGIS v. 9.3 was then used to calculate the amount of built-up area within each circle; and the relative entropy values were calculated for each year by using the formula:

$$
E_{n}=\sum_{i}^{n} p_{i} \frac{\log \left(\frac{1}{p_{i}}\right)}{\log (n)}
$$

where $p_{i}=x_{i} / \sum_{i}^{n} x_{i}$ and $x_{i}$ is the density of land development, which equals the amount of built-up land divided by the total amount of land in the $i$ th zone in $n$ total zones [68]. Relative entropy values closer to 0 indicate uniformity and compact or high density urban development that makes the city vulnerable to change; whereas entropy values close to 1 indicate low density urban development and a high degree of urban sprawl causing chaos in providing transportation and utility services; entropy values in the middle between two extremities indicate an organized urban development [4]. Entropy values for each buffer ring were plotted against the buffer distance, and mapped for each of three years to detect the spatial pattern of urban sprawl over time. To map and identify the zones of uniform, organized and chaotic urban sprawl in the study area, the entropy value of each buffer zone was added to obtain a cumulative entropy value which ranges between 0 at centermost buffer ring to the maximum at the 20th ring. The cumulative entropy value was then divided into three equal intervals: buffer zones with values ranging between $0.0-0.33$ would be the zones of uniformity; those between $0.33-0.66$ would be the zones of organized urban development; and those above 0.66 would indicate zones of chaotic urban development. Change of entropy between two time periods indicate the magnitude, direction, and nature of urban sprawl [68]. Therefore, changes in entropy values were computed by subtracting the entropy value of the base year from that of the terminal years as follows:

$$
\Delta E_{n}=E_{n}(t+1)-E_{n}(t)
$$

where, $t$ and $t+1$ respectively indicate the base year and the terminal year. 


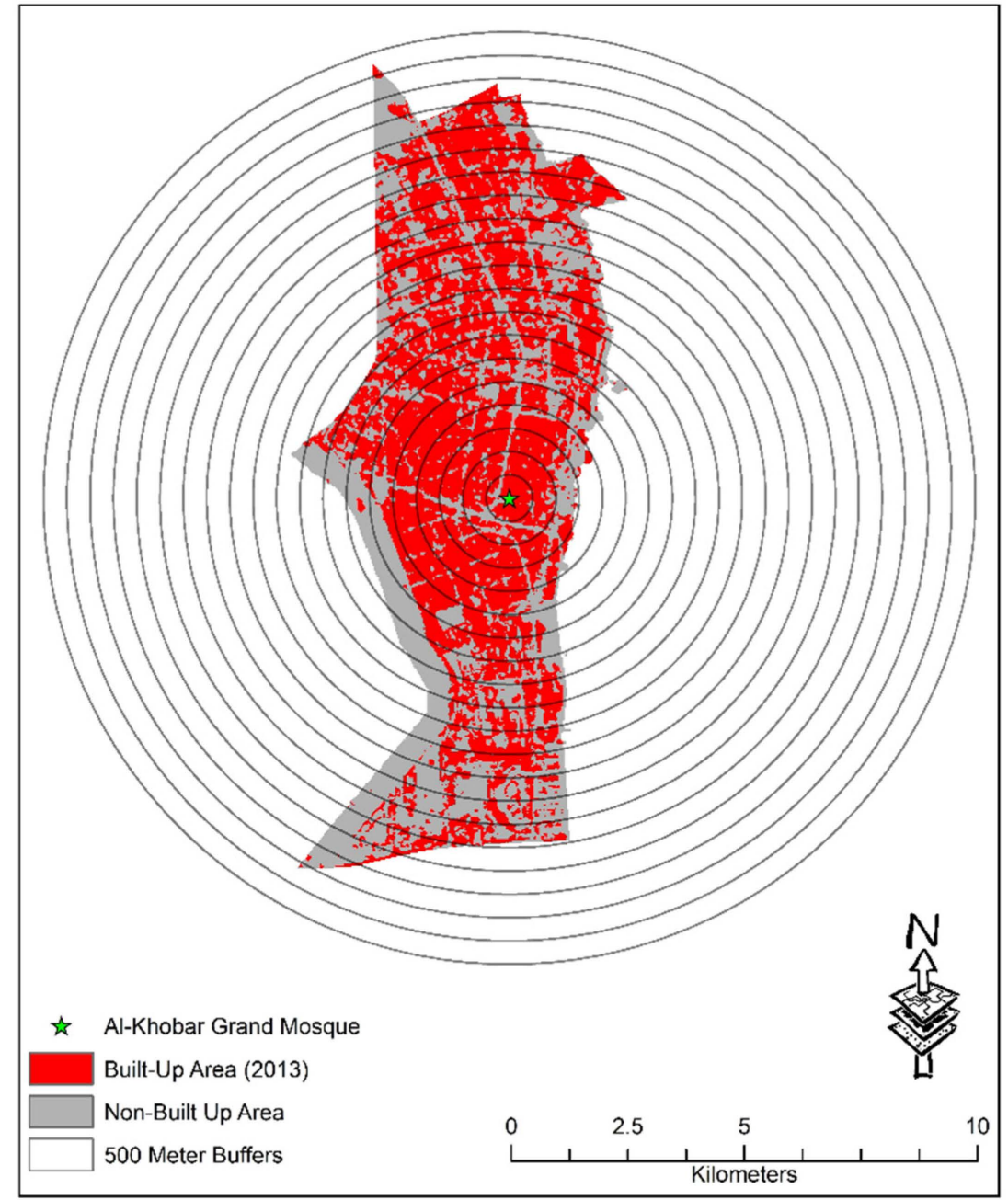

Figure 2. Buffer zones around the Al-Khobar osque used to calculate relative Shannon's entropy index values.

\section{Results}

\subsection{Land Use/Land Cover (LULC) Change in Al-Khobar}

The land cover classification results using the ISODATA classification method for the three time periods within the study area are given in Figure 3. The areal statistics for each land cover class over the past two decades are shown in Table 5. The change detection matrices showing the changes between land cover classes from 1990-2001 and 2001-2013 are presented in Tables 6 and 7. Three major LULC changes were identified during the past two decadal periods. First, during the decade 1990-2001, the total built-up area had increased by 1500 ha (117\% increase) at the expense of conversion of 1782 ha ( $25 \%$ of total area or $33 \%$ of bare soil) of bare soil into urban uses (Tables 5 and 6). Most of these conversions took place in the central and northern parts of the study area. Between 2001 and 2013, the urban built-up area had expanded from 2780 ha to 3990 ha, an increase of $212 \%$ from 1990 and a 44\% increase from 2001 (Table 5). These decadal growth rates are significantly higher than the international standards and cities in the United States, Canada, Nepal, India, and China, and the United Kingdom [73-78]. Consequently, almost $47 \%$ of the bare soil was converted to a built-up area, leaving only 2016 ha or $28 \%$ of the study area to be currently covered with bare soil (Tables 5 and 7). 


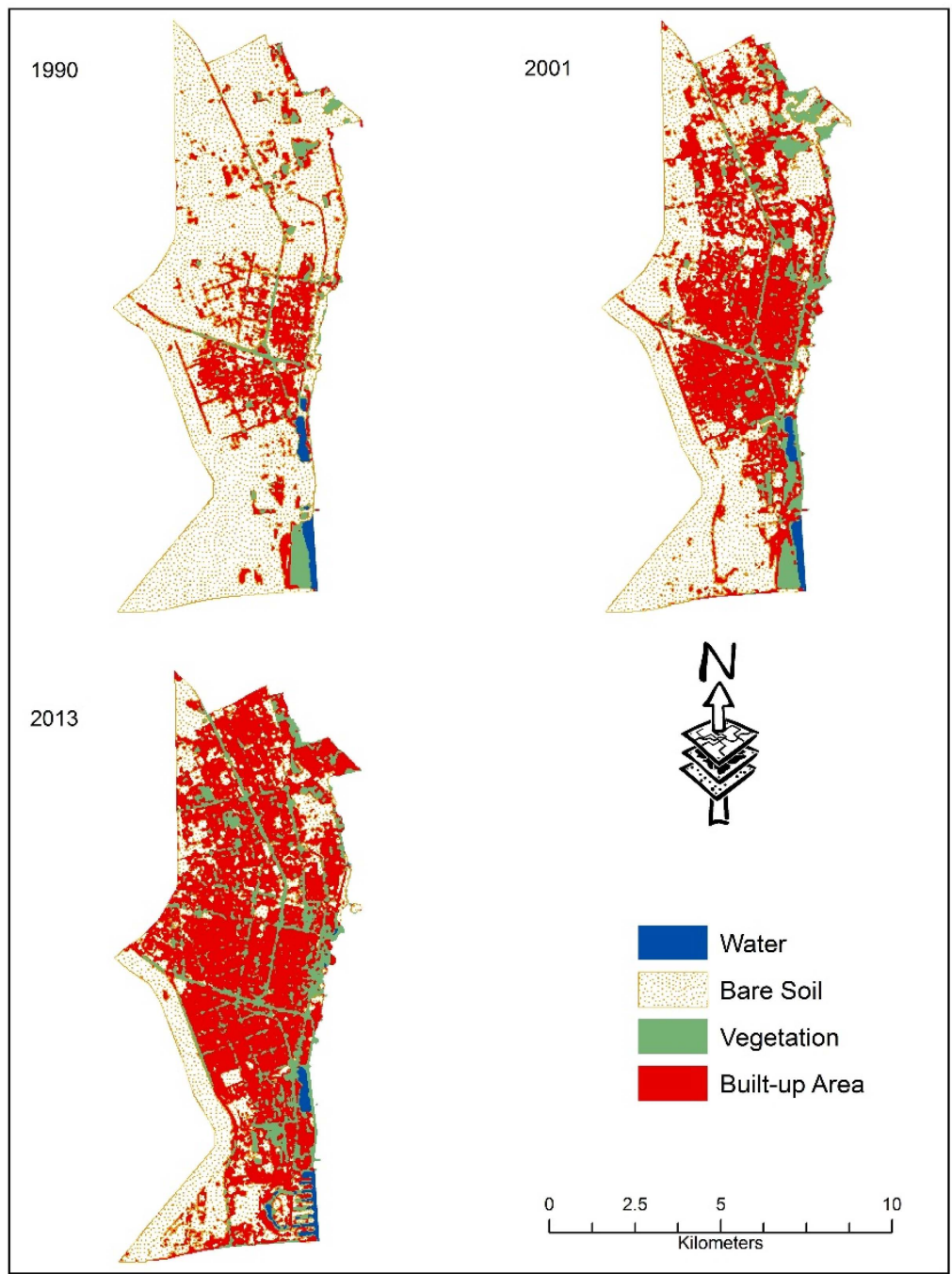

Figure 3. The classified images of the study area for 1990, 2001 and 2013.

Table 5. Land cover in hectare and percentage during 1990, 2001 and 2013.

\begin{tabular}{ccccccc}
\hline & \multicolumn{2}{c}{$\mathbf{1 9 9 0}$} & \multicolumn{2}{c}{$\mathbf{2 0 0 1}$} & \multicolumn{2}{c}{$\mathbf{2 0 1 3}$} \\
\cline { 2 - 7 } & Area (ha) & $\mathbf{\%}$ & Area (ha) & $\mathbf{\%}$ & Area (ha) & \% \\
\hline Water & 144.09 & 2.00 & 101.61 & 1.41 & 110.34 & 1.53 \\
Vegetation & 340.53 & 4.73 & 714.60 & 9.92 & $1,088.73$ & 15.11 \\
Built-Up Area & $1,280.01$ & 17.77 & $2,780.28$ & 38.59 & $3,989.88$ & 55.38 \\
Bare Soil & $5,439.87$ & 75.50 & $3,608.01$ & 50.08 & $2,015.55$ & 27.98 \\
Total & $7,204.50$ & 100.00 & $7,204.50$ & 100.00 & $7,204.50$ & 100.00 \\
\hline
\end{tabular}

Table 6. Change detection matrix showing the class changes between 1990 and 2001.

\begin{tabular}{|c|c|c|c|c|c|c|}
\hline & \multicolumn{6}{|c|}{2001} \\
\hline & & Water & Vegetation & Built-Up Area & Bare Soil & Total \\
\hline \multirow{5}{*}{1990} & Water & 99.81 & 22.77 & 14.85 & 6.66 & 144.09 \\
\hline & Vegetation & 1.44 & 234.81 & 74.07 & 30.21 & 340.53 \\
\hline & Built-Up Area & 0.09 & 255.06 & 909.72 & 115.14 & $1,280.01$ \\
\hline & Bare Soil & 0.27 & 201.96 & $1,781.64$ & 3,456 & $5,439.87$ \\
\hline & Total & 101.61 & 714.6 & $2,780.28$ & $3,608.01$ & $7,204.50$ \\
\hline
\end{tabular}


Table 7. Change detection matrix showing the class changes between 2001 and 2013.

\begin{tabular}{ccccccc}
\hline & \multicolumn{6}{c}{2013} \\
\cline { 2 - 7 } & & Water & Vegetation & Built-Up Area & Bare Soil & Total \\
\hline \multirow{4}{*}{2001} & 66.6 & 8.73 & 7.29 & 18.99 & 101.61 \\
& Water & 27.9 & 415.62 & 197.28 & 73.8 & 714.6 \\
& Vegetation & 5.67 & 524.7 & $2,098.08$ & 151.83 & $2,780.28$ \\
& Built-Up Area & 10.17 & 139.68 & $1,687.23$ & $1,770.93$ & $3,608.01$ \\
& Bare Soil & 110.34 & $1,088.73$ & $3,989.88$ & $2,015.55$ & $7,204.50$ \\
\hline
\end{tabular}

Second, significant changes also occurred in the area under vegetation which increased from 341 ha in 1990 to 715 ha in 2001 and to 1089 ha in 2013 (Table 5). This staggering increment in vegetation coverage occurred as 255 ha of built-up area were converted into green space during the first decade (1990-2001) and another 525 ha of built-up area were transformed into green space during the last decade. Figure 3 shows that the growth of vegetation occurred in the northwestern and along the central eastern coastal seafront of the city and can be classified into three main categories: grasses, date palm trees (Phoenix dactylifera), and other imported trees (Pithecellobium dulce, Prosopis spp.) adaptable to an arid environment.

Finally, the total area under water body declined by about 34 ha between 1990 and 2013, although its inter-decadal growth was observed from 2001 and 2013 (Table 5). As observed during 2001-2013, about 28 ha of vegetation, 6 ha of built-up, and 10 ha bare soils were converted into water body (Table 7). While most of the inland water bodies remained unchanged, some vegetation-covered coastal areas, small roads and paved areas and bare soils in the southeastern coastal seafront of the city were cleared and new inland channels were created to build resorts, shopping malls, and residential hotels. It is possible that some of the conversion of vegetation to water (as detected from the remote sensing data) is likely due to misclassifications between sea weeds and water in the sea-front and coastal areas.

\subsection{Population Growth}

The city of Al-Khobar has experienced rapid population growth and urban sprawl since the 1980s. In 1980, the city had a total population of 104,000 living on 509 ha of built-up area [3]. During $1980-1990$, the city population increased by $36 \%$ and an additional 771 ha $(+150 \%)$ of bare soil was converted into built-up area which in turn reduced the built-up area population density by $46 \%$ (Table 8). From 1990-2001, the city had experienced a staggering $222 \%$ increase in its total population, and about 1500 ha $(+117 \%)$ was converted into urban built-up area. The built-up area population density increased by 40\%. However, per person land conversion decreased from $200 \mathrm{~m}^{2}$ in 1990 to $48 \mathrm{~m}^{2}$ indicating that a large number of new settlers were accommodated in the older part of the city center increasing its compactness (Table 8). During 2001-2013, the city population grew by $48.9 \%$; the built-up area expanded by $43.5 \%$; and the built-up area population density increased by only $3 \%$ from 164 to $170 /$ ha indicating the occurrence of major urban sprawl and a dispersed outward expansion of the city instead of an increased compactness of the old city as observed during the previous decade.

Table 8. Population growth and urban sprawl in Al-Khobar: 1990-2013.

\begin{tabular}{ccccc}
\hline Year & Total Population & Built-Up Area (ha) & $\begin{array}{c}\text { Number of } \\
\text { People/Built-Up Area (ha) }\end{array}$ & $\begin{array}{c}\text { Change in Built-Up Area/Per } \\
\text { Person Population Increase }\end{array}$ \\
\hline 1990 & 141,683 & 1280 & $111(-46 \%)$ & $200 \mathrm{~m}^{2}$ \\
2001 & 456,559 & 2780 & $164(+40 \%)$ & $48 \mathrm{~m}^{2}$ \\
2013 & 679,988 & 3990 & $170(+3 \%)$ & $54 \mathrm{~m}^{2}$ \\
\hline
\end{tabular}




\subsection{Urban Sprawl}

The relative Shannon's entropy for the years 1990, 2001, and 2013 are provided in Table 9. The values are lower than for the major cities of China and Canada but are equivalent or greater than the growing cities of developing countries including India, Nigeria, Iran, and Libya $[24,64,65,79,80]$. For this study, four types of urban sprawls were noticed in 1990: radial pattern and landfill at the city center; leapfrog pattern outside the city center; and elongated strips along HWY 605 and 617. Spatially, a high-density (cumulative entropy 0-0.33) urban development occurred in a radial pattern covering 354 ha of land in three innermost buffer zones from the city center in Al-Khobar (north and south) and Madinat Al Umal districts. Numerous landfills also existed inside the zone. This area was the zone of uniformity where the old city existed with a high degree of compact urban development. A medium-density (cumulative relative entropy of $0.33-0.66$ ) leapfrog pattern of urban development occupied 773 ha in between the 4th and 12th buffer zone. Low-density (cumulative entropy > 0.66) elongated strips of urban sprawl consumed 153 ha of land along HWY 605 and 617 (Figure 4). Increasing entropy values reveal that since the 1990s, urban infrastructures have been growing in a dispersed pattern toward the northern and western districts of Al Rakah Al-Janubiyah, Al Ulaya, Qortoba, and in the northeastern coastal areas. After considering the declining availability of vacant land in the center, the Al-Khobar municipality urged residents and real estate developers to build new urban infrastructures and residential communities in the northern and western parts of the city.

Table 9. Temporal changes in areas under urban sprawl in Al-Khobar: 1990-2013.

\begin{tabular}{cccccc}
\hline Year & \multicolumn{2}{c}{$\begin{array}{c}\text { Area in ha under Each Zone with } \\
\text { Cumulative Entropy Values }\end{array}$} & \multirow{2}{*}{$\begin{array}{c}\text { Total Built-Up } \\
\text { Area in ha }\end{array}$} & $\begin{array}{c}\text { Relative Shannon's } \\
\text { Entropy Values }\end{array}$ \\
\cline { 2 - 4 } & $\mathbf{0 - 0 . 3 3}$ & $\mathbf{0 . 3 3}-\mathbf{0 . 6 6}$ & $\mathbf{> 0 . 6 6}$ & & \\
\hline 1990 & 354 & 773 & 153 & 1,280 & 0.700 \\
2001 & 519 & 1,557 & 704 & 2,780 & 0.779 \\
2013 & 561 & 1,926 & 1,503 & 3,990 & 0.840 \\
\hline
\end{tabular}

In the years 1990-2001, major urban development occurred in the city as its population grew 2.2-fold. The calculated relative entropy was 0.78 , which was $0.08(+11.4 \%)$ higher than for 1990, thereby indicating that low-density dispersed urban development took place mostly in the north side of the city along HWY 605 connecting Khobar and Dammam (Figure 4). Low cumulative entropy (0-0.33) prevailed up to the third buffer zone occupying 509 ha of land of Thuqbah and the north and south Al-Khobar districts where a high-density compact radial pattern of urban development with fewer landfills indicated uniformity with old buildings, damaged roads, and poor quality of utility services. A medium-density (cumulative relative entropy of 0.33-0.66), somewhat organized leapfrog urban development occurred during this decade in the districts of Al Ulaya in the west; Al Hada, Al Hizam Al-Thahabi in the north; and Thuqbah and Iskan in the south from 4th-10th buffer zones covering 1557 ha (an increase of 101\% from 1990). Elsewhere in the Al Jawarah, Al Rawabi, Qortoba Quarter, Al Rakah Al-Janubiyah, and Sports City districts in the north, and Ibn Sina, Al Hamra, and Al Taawun districts in the south, scattered leapfrog and landfill urban development consumed 704 ha of built-up land area, thus indicating a 360\% increase in low-density (cumulative relative entropy of 0.61-0.78) urban sprawl.

By 2013, the city had further experienced low-density dispersed urban sprawl as indicated by the higher relative entropy value of 0.84 ( 0.06 or $8 \%$ higher than 2001). At this time, high-density urban development (cumulative relative entropy values $<0.33$ ) expanded and occupied 561 ha $(8 \%$ increase from 2001) of land at the central part up to the third buffer zone, subsequently indicating continued uniformity (Figure 4). A medium-density organized urban development (cumulative relative entropy values $0.33-0.66)$ occupying 4th to 9th buffer zone expanded by 369 ha (+24\%) from 1557 ha in 2001 
to 1926 ha in 2013. This zone is characterized by newly built or remodeled residential and business establishments in the Al Ulaya, Thuqbah, Al Aqrabiyah, Al Hada, and Iskan districts. Elsewhere in the southern and northern parts of the city, a significant 113\% (704 ha to 1503 ha) increment in low-density landfill and scattered leapfrog urban development (cumulative relative entropy values of 0.66-0.84) occurred from 2001-2013 (Figure 4). This is the chaos zone where numerous newly built, expensive residential houses await leasing. There are also new paved streets, hypermarkets, mosques, and shopping malls still under construction.

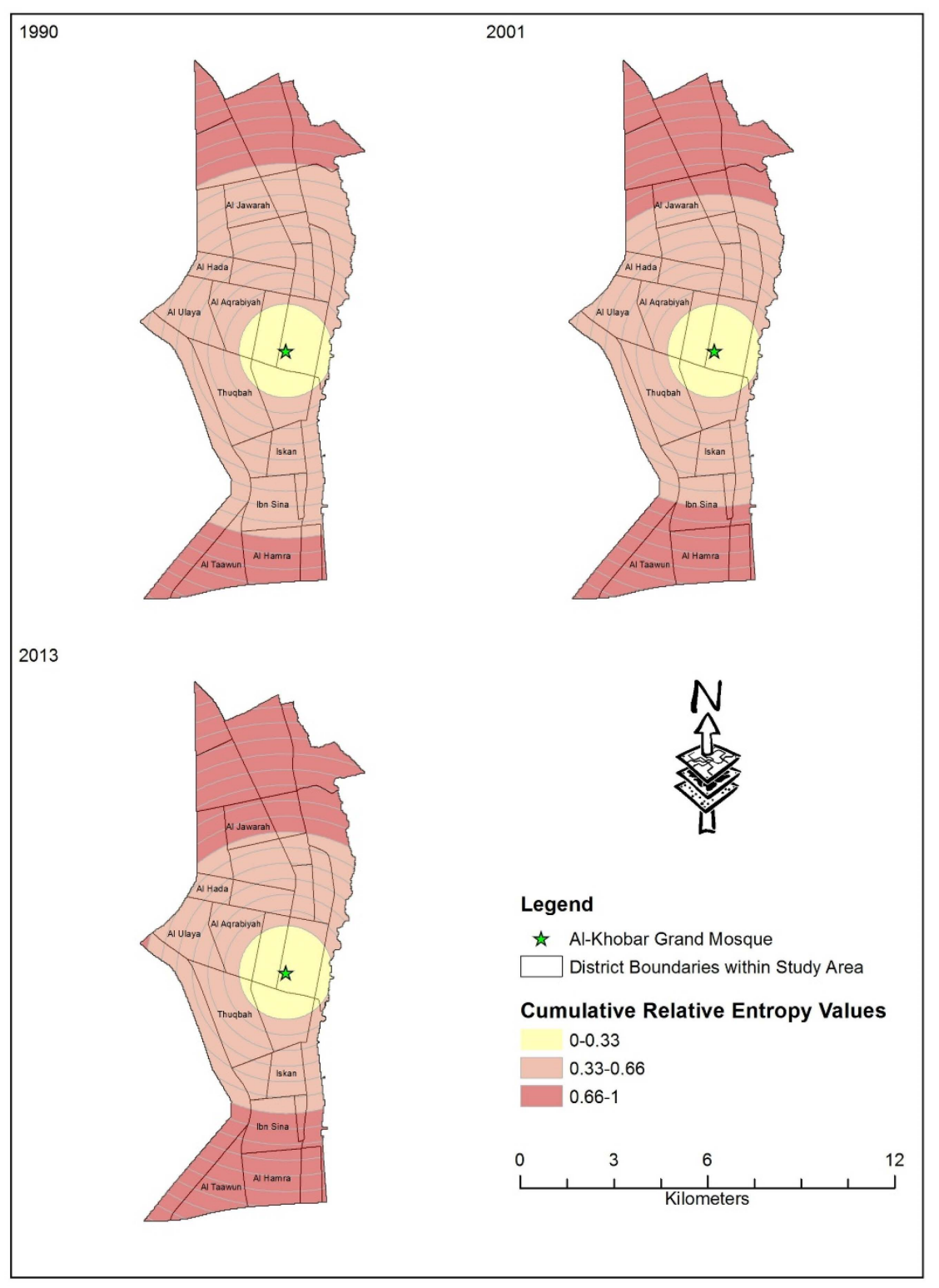

Figure 4. The distribution of the cumulative Shannon's entropy values in the study area.

\section{Discussions}

By using the Landsat images for the years 1990, 2001 and 2013, this study identified water bodies, vegetation, built-up areas, and bare soils as four major LULC classes that have undergone significant changes in the city of Al-Khobar, thereby indicating rapid urban sprawl due to population growth and economic developments in Saudi Arabia's Eastern province. Most notable among LULC changes was the conversion of bare soil into built-up area and manmade vegetation or the creation of green spaces. The city has received almost 539,000 people during the twenty-year period (1990-2013) owing 
to international migration of refugees and foreign troops during the Gulf Wars in 1990 and 2001, in addition to the massive influx of expatriate workers during the oil-based economic growth of the last decade [81-83]. To accommodate the new settlers and provide them with various services, residential compounds and apartments, commercial centers, new residential hotels, restaurants, healthcare centers, and other social service facilities were also built during 1995-2001 in the districts of Thuqbah, Al Aqrabiyah, Al Hizam Al-Akhdar, Qortoba Quarter, Al Rakah Al-Janubiyah, and along the corridor of the Dammam-Khobar highway.

With economic prosperity and increasing population during the past decade, Saudi residents began to invest in real estate by constructing new private residential and commercial housing and properties. Furthermore, the government's land grant policy and the interest-free loan assisted middle class and low-income Saudis to obtain land and build personal residential houses and villas [84]. From 2004 to 2010, almost 14,000 new residential housing units, including villas, apartments, and traditional houses were built in the Al Ulaya, Al Hada, Al Andalus, Al Rawabi, and Al-Bustan districts in the northern and western parts of the study area [36]. At the same time, the construction of urban infrastructures, including roads, highways, schools, residential hotels, mosques, banks, shopping centers, and healthcare facilities, also contributed to the major urban sprawl in the city.

Findings of the study have several methodological and LULC planning implications. First, from the LULC classification methodology perspective, the study attempted to classify Landsat images using a supervised MLC method that yielded a lower accuracy level due to spectral confusions created by the overlapping of bare sandy desert soil with the similarly colored concrete building structures in the built-up areas. This finding is supported in the literature. Lower accuracy level in MLC was reported in other studies due to higher spectral confusion [51], coarse spatial resolution [85], and overlapping of mixed land uses and a high degree of sensitivity and complex spectral variations in land cover in the area $[48,86]$. Lower accuracy level of MLC results were also reported in a land use classification study of a similar desert environment in Israel [86]. The study also found higher accuracy in LULC classifications using the unsupervised ISODATA algorithm in the desert environment [86].

Second, the study has explored the rate, direction and patterns of urban sprawl in the selected city. Findings on urban sprawl suggest very low cumulative relative entropy, in turn indicating uniformity of high-density urban development in the old city center and its immediate neighboring areas; medium to high relative entropy in the organized newly developed areas in between the city center and the city periphery; and high relative entropy due to recent urban developments in the chaotic scattered city periphery. This finding supports the scheme of [4] for classifying urban sprawl.

Third, from an urban planning perspective, the study results show that significant LULC and rapid urban sprawl occurred in the study area, thereby demanding careful planning for all subsequent construction. Over time, each of the uniform, organized, and chaotic zones of urban sprawl has grown in size, suggesting the growing compactness of urban development in the central city, rapid consumption of vacant lots in the organized zone, and major modification of natural landscape in the peripheral chaotic zone to build new houses and utility service facilities. Such modification of the natural landscape may have affected the city water drainage and flood control systems as evidenced in the recent occurrence of flash flooding in the city after winter rain. Rapid urban sprawl has deteriorated the transportation, water, sewage, and utility service facilities in the study area as evidenced by rush-hour traffic congestions in the central city, interrupted water supplies, and lack of hospital services in the chaotic city periphery.

\section{Conclusions}

This study has taken considerable interest in understanding the dynamics of LULC changes and urban sprawl in the city of Al-Khobar, Saudi Arabia by analyzing multi-temporal Landsat data. Using the temporal Landsat images for the years 1990, 2001 and 2013, the study has classified LULC types of the study area by first using maximum likelihood classification (MLC) method followed by the unsupervised ISODATA algorithm. It tested the accuracy of LULC classification for both methods. The 
ISODATA algorithm yielded higher accuracy in LULC classification from the remote sensing images. The study also detected the LULC changes over the periods and found significant increases in the area under built-up area at the expense of sandy bare soils indicating major urban sprawl during the past two decades. Rapid population growth and regional economic development were two factors inducing much faster urban sprawl. Quiet uniform compact urban development at the city center and its immediate vicinity, somewhat chaotic scattered urban development in the city periphery, and much organized urban development between the city center and the city periphery characterized the urban sprawl pattern in the city. While the study results have both methodological and policy implications, future research should explore the physical-environmental, economic and social characteristics of the uniform, organized, and chaotic zones of urban sprawl in the city. Such future research would help planning the development of an environmentally sustainable city in the Eastern province of the Kingdom of Saudi Arabia.

Acknowledgments: The author acknowledges and appreciates the support provided by King Abdulaziz City for Science and Technology (KACST) through the Science \& Technology Unit at King Fahd University of Petroleum \& Minerals (KFUPM) for funding this work through project number 13-ENE198-04 as part of the "National Science, Technology and Innovation Plan (NSTIP)". The author would also like to thank the three anonymous referees for their valuable comments on this manuscript.

Conflicts of Interest: The authors declare no conflict of interest.

\section{References}

1. Alphan, H. Land-use change and urbanization of Adana, Turkey. L. Degrad. Dev. 2003, 14, 575-586. [CrossRef]

2. Dewan, A.M.; Yamaguchi, Y. Land use and land cover change in Greater Dhaka, Bangladesh: Using remote sensing to promote sustainable urbanization. Appl. Geogr. 2009, 29, 390-401. [CrossRef]

3. Aldosary, A.S.; Khan, F. A GIS based assessment of urban sprawl in North Khobar. Int. J. Arab Cult. Manag. Sustain. Dev. 2010, 1, 254-275.

4. Cabral, P.; Augusto, G.; Tewolde, M.; Araya, Y. Entropy in urban systems. Entropy 2013, 15, 5223-5236. [CrossRef]

5. Xu, L.; Li, Z.; Song, H.; Yin, H. Land-use planning for urban sprawl based on the CLUE-S model: A case study of Guangzhou, China. Entropy 2013, 15, 3490-3506. [CrossRef]

6. Byomkesh, T.; Nakagoshi, N.; Dewan, A.M. Urbanization and green space dynamics in Greater Dhaka, Bangladesh. Landsc. Ecol. Eng. 2012, 8, 45-58. [CrossRef]

7. Benitez, G.; Perez-Vazquez, A.; Nava-Tablada, M.; Equihua, M.; Alvarez-Palacios, J.L. Urban expansion and the environmental effects of informal settlements on the outskirts of Xalapa City, Veracruz, Mexico. Environ. Urban. 2012, 24, 149-166. [CrossRef]

8. Seto, K.C.; Guneralp, B.; Hutyra, L.R. Global forecasts of urban expansion to 2030 and direct impacts on biodiversity and carbon pools. Proc. Natl. Acad. Sci. USA 2012, 109, 16083-16088. [CrossRef] [PubMed]

9. Wilson, B.; Chakraborty, A. The environmental impacts of sprawl: Emergent themes from the past decade of planning research. Sustainability 2013, 5, 3302-3327. [CrossRef]

10. Dewan, A.M.; Kabir, M.H.; Nahar, K.; Rahman, M.Z. Urbanisation and environmental degradation in Dhaka Metropolitan Area of Bangladesh. Int. J. Environ. Sustain. Dev. 2012, 11, 118-147. [CrossRef]

11. Yuan, F.; Sawaya, K.E.; Loeffelholz, B.C.; Bauer, M.E. Land cover classification and change analysis of the Twin Cities (Minnesota) Metropolitan Area by multitemporal Landsat remote sensing. Remote Sens. Environ. 2005, 98, 317-328. [CrossRef]

12. Chen, M.; Zhang, H.; Liu, W.; Zhang, W. The global pattern of urbanization and economic growth: Evidence from the last three decades. PLoS ONE 2014, 9, e103799. [CrossRef] [PubMed]

13. Qiao, Z.; Tian, G.; Xiao, L. Diurnal and seasonal impacts of urbanization on the urban thermal environment: A case study of Beijing using MODIS data. ISPRS J. Photogramm. Remote Sens. 2013, 85, 93-101. [CrossRef]

14. Seilheimer, T.S.; Wei, A.; Chow-Fraser, P.; Eyles, N. Impact of urbanization on the water quality, fish habitat, and fish community of a Lake Ontario marsh, Frenchman's Bay. Urban Ecosyst. 2007, 10, 299-319. [CrossRef] 
15. Dewan, A.M.; Islam, M.M.; Kumamoto, T.; Nishigaki, M. Evaluating flood hazard for land-use planning in Greater Dhaka of Bangladesh using remote sensing and GIS techniques. Water Resour. Manag. 2007, 21, 1601-1612. [CrossRef]

16. Nahiduzzaman, K.M.; Aldosary, A.S.; Rahman, M.T. Flood induced vulnerability in strategic plan making process of Riyadh city. Habitat Int. 2015, 49, 375-385. [CrossRef]

17. Bhatta, B. Urban growth and sprawl. In Analysis of Urban Growth and Sprawl from Remote Sensing Data; Springer: Berlin, Germany, 2010; pp. 13-17.

18. Squires, G.D. Urban Sprawl: Causes, Consequences and Policy Responses; The Urban Institute Press: Washington, DC, USA, 2002.

19. Mallupattu, P.; Reddy, J.S. Analysis of land use/land cover changes using remote sensing data and GIS at an Urban Area, Tirupati, India. Sci. World J. 2013, 2013, 1-6. [CrossRef] [PubMed]

20. Rynganga, P.K.; Rynthathiang, B.B.L. Dynamics of land use land cover for sustainability: A case of Shillong, Meghalaya, India. Int. J. Sci. Technol. Res. 2013, 2, 235-239.

21. Shalaby, A.; Tateishi, R. Remote sensing and GIS for mapping and monitoring land cover and land-use changes in the northwestern coastal zone of Egypt. Appl. Geogr. 2007, 27, 28-41. [CrossRef]

22. Dewan, A.M.; Yamaguchi, Y.; Rahman, M. Dynamics of land use/cover changes and the analysis of landscape fragmentation in Dhaka Metropolitan, Bangladesh. GeoJournal 2010, 77, 315-330. [CrossRef]

23. Ahmed, B.; Kamruzzaman, M.; Zhu, X.; Rahman, M.S.; Choi, K. Simulating land cover changes and their impacts on land surface temperature in Dhaka, Bangladesh. Remote Sens. 2013, 5, 5969-5998. [CrossRef]

24. Sun, H.; Forsythe, W.; Waters, N. Modeling urban land use change and urban sprawl: Calgary, AB, Canada. Netw. Spat. Econ. 2007, 7, 353-376. [CrossRef]

25. Hassan, S.; Mahmud-Ul-Islam, S.; Rahman, M.T. Integration of remote sensing and GIS to assess vulnerability of environmental degradation in North-Western Bangladesh. J. Geogr. Inf. Syst. 2015, 7, 494-505. [CrossRef]

26. Rahman, M.T.; Rashed, T. Urban tree damage estimation using airborne laser scanner data and geographic information systems: An example from 2007 Oklahoma ice storm. Urban For. Urban Green. 2015, 14, 562-572. [CrossRef]

27. Corner, R.J.; Dewan, A.M.; Chakma, S. Monitoring and prediction of land-use and land-cover (LULC) change. In Dhaka Megacity: Geospatial Perspectives on Urbanisation, Environment and Health; Dewan, A.M., Corner, R.J., Eds.; Springer: Houten, The Netherlands, 2014; pp. 75-97.

28. Ahmed, S.; Bramley, G.; Dewan, A. Exploratory growth analysis of a megacity through different spatial metrics: A case study on Dhaka, Bangladesh (1960-2005). URISA J. 2012, 24, 9-24.

29. Rahman, M.T. Integration of remote sensing and GIS for tree damage estimation from natural disasters. In Proceedings of the 34th International Symposium on Remote Sensing of Environment, The GEOSS Era: Towards Operational Environmental Monitoring, Sydney, NSW, Australia, 10-15 April 2011.

30. Yuan, D.; Elvidge, C.D.; Lunetta, R.S. Survey of multispectral methods for land cover change analysis. In Remote Sensing Change Detection: Environmental Monitoring Methods and Applications; Ann Arbor Press: Ann Arbor, MI, USA, 1998; pp. 21-39.

31. Ridd, M.; Liu, J. A comparison of four algorithms for change detection in an urban environment. Remote Sens. Environ. 1998, 63, 95-100. [CrossRef]

32. Singh, A. Digital change detection techniques using remotely-sensed data. Int. J. Remote Sens. 1989, 10, 989-1003. [CrossRef]

33. Lillesand, T.M.; Kiefer, R.W.; Chipman, J.W. Digital image interpretation and analysis. In Remote Sensing and Image Interpretation; John Wiley \& Sons: Hoboken, NJ, USA, 2008; pp. 482-625.

34. Jensen, J.R. Digital change detection. In Introductory Digital Image Processing: A Remote Sensing Perspective; Prentice-Hall: Upper Saddle River, NJ, USA, 2004; pp. 467-494.

35. Coppin, P.; Jonckheere, I.; Nackaerts, K.; Muys, B.; Lambin, E. Digital change detection methods in ecosystem monitoring: A review. Int. J. Remote Sens. 2004, 25, 1565-1596. [CrossRef]

36. CDSI. Statistical Yearbook. Available online: http://www.cdsi.gov.sa/yb46/Pages/MixFPage.htm (accessed on 15 October 2014).

37. Al-Harbi, K.M. Discovering and Detecting Agricultural Change in Eastern Tabuk-Saudi Arabia, Using Remote Sensing Technique (in Arabic); Kuwaiti Geogrpahic Society: Kuwait City, Kuwait, 2003.

38. Al-Harbi, K.M. Monitoring of agricultural area trend in Tabuk region-Saudi Arabia using Landsat TM and SPOT data. Egypt. J. Remote Sens. Sp. Sci. 2010, 13, 37-42. [CrossRef] 
39. ALWASHE, M.A.; BOKHARI, A.Y. Monitoring vegetation changes in Al Madinah, Saudi Arabia, using Thematic Mapper data. Int. J. Remote Sens. 1993, 14, 191-197. [CrossRef]

40. Al-Gaadi, K.A.; Samdani, M.S.; Patil, V.C. Assessment of temporal land cover changes in Saudi Arabia using remotely sensed data precision agriculture research chair, college of food and agriculture sciences. Middle-East J. Sci. Res. 2011, 9, 711-717.

41. Aina, Y.A.; Merwe, J.H.V.; Alshuwaikhat, H.M. Urban spatial growth and land use change in Riyadh: Comparing spectral angle mapping and band ratioing techniques. In Proceedings of the Academic Track of the 2008 Free and Open Source Software for Geospatial (FOSS4G) Conference, incorporating the GISSA 2008 Conference, Cape Town, South Africa, 29 September-3 October 2008; pp. 51-57.

42. Aljoufie, M.; Zuidgeest, M.; Brussel, M.; Maarseveen, M.V. Spatial-temporal analysis of urban growth and transportation in Jeddah City, Saudi Arabia. Cities 2013, 31, 57-68. [CrossRef]

43. World Weather and Climate Information. Average Weather in Al-Khobar, Saudi Arabia. Available online: http:/ / www.weather-and-climate.com/average-monthly-Rainfall-Temperature-Sunshine,al-khobar, Saudi-Arabia (accessed on 5 November 2014).

44. Gilmore, S.; Saleem, A.; Dewan, A. Effectiveness of DOS (Dark-Object Subtraction) method and water index techniques to map wetlands in a rapidly urbanising megacity with Landsat 8 data. In Proceedings of the Research@Locate in Conjunction with the Annual Conference on Spatial Information in Australia and New Zealand, Brisbane, QLD, Australia, 10-12 March 2015; pp. 100-108.

45. LPSO Landsat 7 Science Data User's Handbook. Available online: http://landsathandbook.gsfc.nasa.gov/ pdfs/Landsat7_Handbook.pdf (accessed on 17 August 2015).

46. USGS. Landsat 8 (L8) Data Users Handbook Version 1.0. Available online: http://www.greenpolicy360.net/ $\mathrm{mw} /$ images/Landsat8DataUsersHandbook.pdf (accessed on 19 December 2015).

47. Anderson, J.R.; Hardy, E.E.; Roach, J.T.; Witmer, R.E. A Land Use and Land Cover Classification System for Use with Remote Sensor Data; United States Government Printing Office: Washington, DC, USA, 1976.

48. Campbell, J.B.; Wynne, R.H. Introduction to Remote Sensing, 5th ed.; Guilford Press: New York, NY, USA, 2011.

49. Myint, S.W.; Gober, P.; Brazel, A.; Grossman-Clarke, S.; Weng, Q. Per-pixel vs. object-based classification of urban land cover extraction using high spatial resolution imagery. Remote Sens. Environ. 2011, 115, 1145-1161. [CrossRef]

50. Gu, J.; Congalton, R.; Pan, Y. The impact of positional errors on soft classification accuracy assessment: A simulation analysis. Remote Sens. 2015, 7, 579-599. [CrossRef]

51. Dewan, A.M.; Yamaguchi, Y. Using remote sensing and GIS to detect and monitor land use and land cover change in Dhaka Metropolitan of Bangladesh during 1960-2005. Environ. Monit. Assess. 2009, 150, 237-249. [CrossRef] [PubMed]

52. Tewolde, M.G.; Cabral, P. Urban sprawl analysis and modeling in Asmara, Eritrea. Remote Sens. 2011, 3, 2148-2165. [CrossRef]

53. Ward, D.; Phinn, S.R.; Murray, A.T. Monitoring growth in rapidly urbanizing areas using remotely sensed data. Prof. Geogr. 2000, 52, 371-386. [CrossRef]

54. Congalton, R.G.; Green, K. Advanced topics. In Assessing the Accuracy of Remotely Sensed Data: Principles and Practices; CRC Press: Boca Raton, FL, USA, 2009; pp. 159-171.

55. Cohen, W.B.; Fiorella, M.; Gray, G.; Helmer, E.; Anderson, K. An efficient and accurate method for mapping forest clearcuts in the Pacific Northwest using Landsat imagery. Photogramm. Eng. Remote Sens. 1998, 64, 298-300.

56. Hayes, D.J.; Sader, S. A comparison of change-detection techniques for monitoring tropical forest clearing and vegetation regrowth in a time series. Photogramm. Eng. Remote Sens. 2001, 67, 1067-1075.

57. Stewart, D.; Yin, Z.; Bullard, S.; Maclachlan, J.T. Assessing the spatial structure of urban and population growth in the greater Cairo Area, Egypt: A GIS and imagery analysis approach. Urban Stud. 2004, 41, 95-116. [CrossRef]

58. Corner, R.J.; Ongee, E.T.; Dewan, A.M. Spatiotemporal patterns of population distribution. In Dhaka Megacity: Geospatial Perspectives on Urbanisation, Environment and Health; Dewan, A.M., Corner, R.J., Eds.; Springer: Houten, The Netherlands, 2014; pp. 45-60.

59. Singh, B. Urban growth using Shannon's entropy: A case study of Rohtak City. Int. J. Adv. Remote Sens. GIS 2014, 3, 544-552. 
60. Araya, Y.H.; Cabral, P. Analysis and modeling of urban land cover change in Setúbal and Sesimbra, Portugal. Remote Sens. 2010, 2, 1549-1563. [CrossRef]

61. Bhatta, B.; Saraswati, S.; Bandyopadhyay, D. Urban sprawl measurement from remote sensing data. Appl. Geogr. 2010, 30, 731-740. [CrossRef]

62. Ewing, R. Is Los Angeles-style sprawl desirable? J. Am. Plan. Assoc. 1997, 63, 107-126. [CrossRef]

63. Galster, G.; Hanson, R.; Ratcliffe, M.R.; Wolman, H.; Coleman, S.; Freihage, J. Wrestling sprawl to the ground: Defining and measuring an elusive concept. Hous. Policy Debate 2001, 12, 681-717. [CrossRef]

64. Igbokwe, J.I. Identification of urban sprawl using remote sensing and GIS technique: A case study of Onitsha and its environs in Southeast, Nigeria. Int. J. Remote Sens. Geosci. 2013, 2, 41-49.

65. Li, X.; Yeh, A.G.-O. Analyzing spatial restructuring of land use patterns in a fast growing region using remote sensing and GIS. Landsc. Urban Plan. 2004, 69, 335-354. [CrossRef]

66. Shekhar, S. Urban Sprawl Assessment Entropy Approach. Available online: http://www.archidev.org/ IMG/doc/Urban_sprawl_assessment_Entropy_approach_Pune.doc (accessed on 1 January 2014).

67. Sudhira, H.S.; Ramachandra, T.V.; Jagadish, K.S. Urban sprawl: Metrics, dynamics and modelling using GIS. Int. J. Appl. Earth Obs. Geoinf. 2004, 5, 29-39. [CrossRef]

68. Yeh, A.G.; Li, X. Measurement and monitoring of urban sprawl in a rapidly growing region using entropy. Photogramm. Eng. Remote Sens. 2001, 67, 83-90.

69. Dewan, A.M.; Corner, R.J. Spatiotemporal analysis of urban growth, sprawl and structure. In Dhaka Megacity: Geospatial Perspectives on Urbanisation, Environment and Health; Dewan, A.M., Corner, R.J., Eds.; Springer: Houten, The Netherlands, 2014; pp. 99-121.

70. Shen, G. Fractal dimension and fractal growth of urbanized areas. Int. J. Geogr. Inf. Sci. 2002, 16, 419-437. [CrossRef]

71. Ayhan, I.; Mert Cubukcu, K. Explaining historical urban development using the locations of mosques: A GIS/spatial statistics-based approach. Appl. Geogr. 2010, 30, 229-238. [CrossRef]

72. Bonine, M.E. The morphogenesis of Iranian Cities. Ann. Assoc. Am. Geogr. 1979, 69, 208-224. [CrossRef]

73. Hart, J.F. Urban encroachment on rural areas. Geogr. Rev. 1976, 66, 1-17. [CrossRef]

74. Alig, R.; Healy, R. Urban and built-up land area changes in the United States: An empirical investigation of determinants. Land Econ. 1987, 63, 215-226. [CrossRef]

75. Mohapatra, S.N.; Pani, P.; Sharma, M. Rapid urban expansion and its implications on geomorphology: A remote sensing and GIS based study. Geogr. J. 2014, 2014, 1-10. [CrossRef]

76. Thapa, R.B.; Murayama, Y. Examining spatiotemporal urbanization patterns in Kathmandu Valley, Nepal: Remote sensing and spatial metrics approaches. Remote Sens. 2009, 1, 534-556. [CrossRef]

77. Leamy, M.I. Resources of highly productive land. New Zeal. Agric. Sci. 1974, 8, 187-191.

78. Edwards, A.M. Land requirement for UK agriculture by the year 2000: A preliminary statement. T. Ctry. Plan. 1969, 37, 108-150.

79. Al-sharif, A.A.A.; Pradhan, B.; Shafri, H.Z.M.; Mansor, S. Spatio-temporal analysis of urban and population growths in tripoli using remotely sensed data and GIS. Indian J. Sci. Technol. 2013, 6, 5134-5142.

80. Dadras, M.; Shafri, H.Z.M.; Ahmad, N.; Pradhan, B.; Safarpour, S. Six decades of urban growth using remote sensing and GIS in the city of Bandar Abbas, Iran. In Proceedings of 7th IGRSM International Remote Sensing \& GIS Conference and Exhibition, Kuala Lumpur, Malaysia, 21-22 April 2014.

81. Galbraith, P. Refugees from the War in Iraq: What Happened in 1991 and What May Happen in 2003. Avaiable online: http:/ / www.migrationpolicy.org/research/refugees-war-iraq-what-happened-1991-and-what-mayhappen-2003 (accessed on 6 June 2015).

82. Index Mundi Saudi Arabia Crude Oil Production by Year. Available online: http://www.indexmundi.com/ energy.aspx?country=sa\&product=oil\&graph=production (accessed on 10 November 2014).

83. Abou-Korin, A.A. Impacts of rapid urbanisation in the Arab World: The case of Dammam Metropolitan Area, Saudi Arabia. In Proceedings of 5th International Conference and Workshop on Built Environment in Developing Countries (ICBEDC 2011), Penang, Malaysia, 6-7 December 2011; pp. 1-25.

84. Al-Hathloul, S.; Mughal, M.A. Urban growth management-The Saudi experience. Habitat Int. 2004, 28, 609-623. [CrossRef] 
85. Haac, B.; Bryant, N.; Adams, S. An assessment of Landsat MSS and TM data for urban and near urban land cover digital classification. Remote Sens. Environ. 1987, 21, 201-213. [CrossRef]

86. Rozenstein, O.; Karnieli, A. Comparison of methods for land-use classification incorporating remote sensing and GIS inputs. Appl. Geogr. 2011, 31, 533-544. [CrossRef]

(c) 2016 by the author; licensee MDPI, Basel, Switzerland. This article is an open access article distributed under the terms and conditions of the Creative Commons by Attribution (CC-BY) license (http://creativecommons.org/licenses/by/4.0/). 